\title{
Physical Activity During Therapy of Self- Disorder Among Patients With Schizophrenia.A Phenomenological Understanding of the Relationship Between Healing and Physical Activity
}

Authors' contribution:

A) conception and design of the study

B) acquisition of data

C) analysis and interpretation of data

D) manuscript preparation

E) obtaining funding

\section{Jim Toft}

Center for Social Psychiatry (Slagelse Municipality), Denmark

ABSTRACT

Studies indicate that physical activity has a positive effect both physiologically and socially for psychologically ill and vulnerable people, and that this effect is the same or greater for psychologically well-functioning people. In spite of this, treatment sites often hesitate to include sports and physical activity as part of the treatment offered. This article argues that there is a strong correlation between the body and mind, but from a different point of view than that adopted by the prevalent scientific research in the field. Specifically, I elucidate how the mind-body relationship and self-consciousness are influenced by physical activity for people with schizophrenia, and argue that symptoms are relieved as a result of physical activity. Consciousness has a bodily component that, for people with schizophrenia, is less well-integrated in the consciousness than for psychologically well-functioning people, and sports and physical activity can help facilitate this integration. My argument is based partly on phenomenological concepts and partly on an empirical research project concerning physical activity for people with schizophrenia. The conclusion is that their level of functioning and self-assessed quality of life increased markedly through physical activity. The purpose of the present article is thus partly to qualify the treatment chosen for people with schizophrenia, and partly to qualify the theoretical discussion concerning the role played by the body and physical activity in connection with consciousness and relief.

KEYWORDS physical activity, therapy, self-disorder, schizophrenia

\section{Introduction}

"In a world where education is predominantly verbal, highly educated people find it but impossible to pay serious attention to anything but words and notions. There is always money for, there are always doctorates in, the learned foolery of research into what, for scholars, is the all-important problem: who influenced whom to say what when? The non-verbal humanities, 
the arts of being directly aware of the given facts of our existence, are almost completely ignored" (Aldous Huxley, The Doors of Perception, 1954).

Recently, a leading Danish psychiatrist asked the critical question: "Is psychiatry bodiless?" (Jørgensen, 2012). He did so even though studies indicate that physical activity has a positive effect both physiologically and socially for psychologically ill and vulnerable people, and that this effect is the same or greater for psychologically well-functioning people (Nordentoft et al., 2012; Pedersen \& Andersen, 2011; Daley, 2002; Faulkner, 2005; Faulkner \& Biddle, 1999; Faulkner \& Sparkes, 1999; Holley et al., 2011; Biddle \& Mutrie, 2008). In spite of this, treatment sites often hesitate to include sports and physical activity as part of the treatment offered (Faulkner, 2005; Daley, 2002; Biddle, 2008; Craft \& Landers, 1998). When it comes to choosing a method, reflection and psycho-education are given higher priority and, as expressed by Aldous Huxley in the above quotation, the non-verbal and non-rational are usually referred to the background.

In this article, I focus on how physical activity may be used as an advantage in the treatment of people with schizophrenia and how the body as a subject is often overlooked in the understanding of this illness. First, I present the findings from the empirical part of my research project (Toft, 2011). The aim was to examine how physical activity may affect the symptoms, behavior, and consciousness of people with schizophrenia. More specifically, the aim was to examine how physical activity affected the experience of being in the world for a number of people with schizophrenia, rather than how it affected their physical fitness and health, which are the measurable parameters usually employed in studies concerning physical activity. I thus chose to base the study on qualitative methods and used phenomenological concepts to gain an understanding of the role played by the body in relation to the mind.

Second, I describe the theoretical foundation for how physical activity affects the self-disorders observed in people with schizophrenia. Based on phenomenological theory, I present the hypothesis that the self is rooted in the body and that physical activity may help integrate the self as well as improve contact between the self and others. I thus lay the groundwork for an understanding of physical activity that emphasizes the importance of the subjectivity and experience of the practitioner. I also elevate the understanding of the effect of physical activity to a higher level than is usually observed in the field of psychiatry, where the effect is only understood in terms of physical relief and relaxation. I argue that physical activity in itself may have a healing effect on the self and on self-disorders and that it may be employed as a treatment method to a far greater extent than it is at present.

My argument is thus one in favor of the widely acknowledged point that there is a strong correlation between the body and mind, however it comes from a different point of view than the one that has been adopted by the prevalent scientific research in the field.

\section{PART 1}

\section{Examples}

I begin by presenting a few examples of people with severe symptoms of schizophrenia who experience that their symptoms ease or completely disappear in connection with physical activity. These examples are taken from the research project mentioned in Toft $(2011,2014)$.

The first example is of a middle-aged man who was diagnosed with paranoid schizophrenia. In the ward, he was playing football, a sport he used to play as a child. After the training, he looked surprised and happy and exclaimed to a nearby employee: "Wow, my voices disappeared!".

The second example is of a man in his early fifties who was diagnosed with paranoid schizophrenia and OCD and had been placed in a secure ward for most of his life. He had not been to a swimming pool for approximately 30 years. After swimming 20 meters, he stood up, looked the employee in the eyes and said: "I can feel myself!". 
In the last example, an employee who was the contact person for a woman in her mid-thirties, whom he had followed closely as a patient for 7 years, said of the woman in question:

"When she enters the ward [after having been physically active]-and this is probably the only time when I can say this of her-she seems awake".

Not only are these examples a strong attestation that physical activity may relieve the symptoms of psychological vulnerability, but they also illustrate the strong correlation between body and mind that may be evidenced in people with schizophrenia in connection with physical activity. See Toft (2011) for further case material.

\section{Empirical study}

The empirical study was launched in 2006 at the secure ward in Nykøbing Sjælland, Denmark, and lasted until 2010. A secure ward is a place of treatment for people who, due to their illness and previous actions, are considered particularly dangerous. In a secure ward, as opposed to other wards, the outer doors and windows may be permanently locked. Only patients diagnosed with schizophrenia are referred to the secure ward in Nykøbing Sjælland. The ward has a total of 30 patients, with 10 in each subward. Most of the patients are young people in their twenties and thirties. They are typically admitted for relatively long periods, approximately two years on average. At the ward, the patients receive treatment and daily life is characterized by order and routine.

My choice of the secure ward as the site for this research project was based on the fact that sports were the most common treatment option offered to the patients and that the ward employed four physical education teachers to assist the three subwards on a daily basis. This formed a sound research basis for a project on sports and physical activity compared to other treatment wards for people with schizophrenia.

The study was conducted with seven patients in the ward, six men and one woman. These patients were selected at a conference attended by all staff groups in the ward. Following the selection, each of the seven patients was observed for six months by two or three members of the staff who had close contact with the patient in question on a daily basis.

The primary role of the observers was to observe the patients before, during, and after sports and to take notes either during or after observation. Additionally, they were to talk to the patients about their experiences in connection with physical activity, including the effect of physical activity on their functional level. They were interviewed three times concerning the same patient: at the beginning of the project, halfway through the observation period, and at the end of the observation period, which lasted for six months. The total group of observers represented all staff groups, i.e., caregiver, pedagogue, nurse, psychologist, doctor, and occupational therapist, and observations and interviews were equally distributed between these individuals.

The patients, who so wished, five in all, were interviewed about their experiences in connection with physical activity. The remaining two patients either did not wish to be interviewed or were forbidden to be interviewed by the staff for safety reasons.

Before the project, all seven patients were interviewed about their wishes, needs, and previous experiences with sports. This made it possible to choose a kind of physical activity that could motivate the patient. The following kinds of sports and physical activities were chosen: spinning, fitness, dance, and an array of ball games such as football, hockey, basketball, volleyball, table tennis, and foam-ball tennis.

In the following, I present two cases from the research project that represent and illustrate the findings.

\section{Case 1: Peter}

Peter is a young man in his late twenties who had been an inpatient for approximately five years when the project commenced. He suffered from severe psychosis and was diagnosed with catatonic, paranoid 
schizophrenia with massive delusions and thought disorders. It was difficult to conduct an intelligible conversation with Peter, as his language was filled with neologisms and his ability to build a rapport was poor. The staff considered Peter extremely dangerous. He had attacked the staff on several occasions and had thus been restrained for five consecutive years. During those years, he was only allowed out of his room six times a week: three times to have a bath and three times for exercise. Not surprisingly, his daily medicine intake was exorbitant: he was given five times the recommended daily dose.

\section{Peter's physical activities}

Peter himself wished to start taking part in physical activity and had expressed this wish to the staff for some time, but for safety reasons he was only allowed to be physically active in his room. At the beginning of the project, Peter's wish was met by placing exercise bikes in his room for him and the physical education teacher and researcher. However, two additional "safety persons" were to be present in the room during the exercise time. The safety persons were also the contact persons who observed Peter's experience with physical activity for the project. During the project period, Peter cycled two to three times per week.

\section{Peter's development during the observation period}

To begin with, Peter's physical fitness was extremely poor: he was only able to cycle for 10-15 minutes at a low intensity. However, before long, Peter made remarkable progress. He began on his own volition to run in the yard during the three times a week he was allowed out of his room for exercise. His physical fitness quickly improved, and after two months he was able to cycle for 30 minutes. However, based on the assumption that Peter would present a greater safety risk in a more mentally present state, the staff did not wish for Peter to cycle more than twice a week. According to the staff, this assumption was proven correct as Peter began to place larger demands on them to fulfill his needs and wishes. In his improved mental state, Peter started to behave in a threatening manner towards the staff when these needs and wishes were not fulfilled.

During the 12-month project period, Peter changed markedly. Generally, he began to show more strength of will and character and began to place demands on the staff regarding his own situation. His general functional ability improved, which was illustrated when his contact person stated: "I think that he has gradually improved during the three and a half months. My colleagues agree that Peter is better now than anyone here has seen before." In addition, his chief physician observed the following:

"His personality is so disintegrated, that it is difficult to say if it will be possible to integrate him other than in the sports situation itself. However, I would say that it clearly looks as if he became more integrated and were able to speak more coherently".

In the following quotation, which supports the consultant's sense of the development of a larger degree of "integration" in Peter, Peter's contact person points out some more specific changes signifying an improvement in Peter's ability to relate to himself and his surroundings:

"It strengthened his identity that sports was 'him' and the way he ran, even if he sometimes almost had to be supported and helped outside, because he had those negative symptoms he always has when he lies on his bed, seeing how he then found the strength to get going and run those 30 minutes in the yard, it was a completely different person I came to collect from the yard than the person I had taken out there and it was clear that he was happy, that he was proud, and that he was present in his body in a whole other way than when he didn't exercise (...).I think that his speech has become more coherent and that he has become more, I think, aware of his surroundings. Either way, he relates more to what's going on around him(...) and an integration in him to hold on to reality, which I haven't previously seen". 
Peter became able to have a conversation, and his way of speaking and thinking became more coherent after cycling for 10-15 minutes. This progress is highlighted by the following interview with a staff member:

"Staff: Well, Peter feels good about sports and we see that he, especially when he cycles, that he seems more together when he cycles than he otherwise does during usual contact with him. Subsequently, he slowly disintegrates again, but while he cycles, then he is at least usually able to hold contact and hold himself together.

Interviewer: His speech, is that also different when he cycles?

Staff: It is very different. He is, well, usually he is completely clear and relevant when he speaks during cycling.

Interviewer: And what about neologisms?

Staff: Yes, that is unusual. The neologisms are less prominent during the cycling as well, although they reappear afterwards, but during the cycling he is, yes, he is what I would call clear and relevant".

During cycling, Peter himself described his experience positively, by saying things such as "It's amazing to bike", "I want to bike so fast that I cannot feel the consciousness", and "It makes me glad to cycle with you and not alone, and cycling motivates me for the rest of the day. It's a pat on the back for the rest of the day".

It is worth noting that Peter not only felt a physical improvement. He expressed that his thoughts and mood improved during the physical activity and that his "consciousness" receded into the background, allowing an immediate experience of being in the world, self-presence (see Toft, 2011, 2014), to move to the foreground.

Initially, the suggestion that physical activity might have an effect on and meaning for Peter was met with skepticism; however, the physical activity course and its effect on Peter put this skepticism to shame. The observers, Peter himself, and I all agreed that his symptoms became fewer and less prominent. Moreover, it is worth noting that the five previous years of treatment had not resulted in any improvement in Peter. Actually, the physical activity course was the first treatment to produce any apparent results.

\section{Case 2: Morten}

Morten is a young man in his early twenties. Since his teenage years, he has been institutionalized and diagnosed with paranoid schizophrenia, OCD, and a borderline self-disorder with periods of severe anxiety and depression. Morten has a history of suicide attempts and, when the project began, he had a tendency to isolate himself and to avoid eye contact and communication with others. Moreover, during the approximately two years he had been at the secure ward, he gained 77 pounds.

Like Peter, Morten had massive thought and speech disorders. He had major problems concentrating and, focusing, and appeared maintaining thoughts and acts and he gave an impression of lack of initiative and energy. Moreover, psychological tests showed that Morten had poor visuospatial and visuoconstructive skills and a very low psychomotor rate for problem solving.

Morten enjoyed ball games and fitness, and was thus enrolled in a ball game group three times per week and a fitness group two times per week. As with Peter, the staff was initially skeptical of the suggestion that Morten might benefit from a physical activity course. It was thought that Mortens disorders and bodily inhibitions were too severe, and that he had too little will and too much anxiety to participate in such a course. 


\section{Morten's development during the observation period}

As in Peter's case, the staff soon had to adjust their expectations of Morten. Morten's psychologist stated:

"Well, he has become more normal in his relationships. He is able to wait until you have time to speak with him. He no longer has that impatience that he used to have. It's as if he has calmed down. He also listens. If you noticed, he listened to our conversation (...).He usually doesn't do that".

The psychologist who participated in the sports sessions with Morten observed that Morten underwent a change during the physical activity itself. She thus stated that:

"The first time I was out with him, when you [i.e., the interviewer and researcher] were there too, I think that his breathing was also different than when he came in. He seemed to stand taller and to breathe more freely, and he looked happier too, I think (...). It's a question of him feeling better about himself, or it's somehow a question concerning his integrity of sense of self. He is himself, he can stand being near others, the anxiety doesn't flourish in the same way. I don't know what happens, but something happens".

This quotation shows that Morten, during the physical activity itself, was able to be in the company of others, and that his skills of perception during physical activity were remarkably good, far better than assumed and described in his medical record. Morten calmed down, his anxiety lifted, and he was able to approach others and communicate with them, which he usually was not able to do. Moreover, his posture was more erect, which made him seem less despondent than usual.

However, what came as the greatest surprise was Morten's skills and abilities as a ball player. He seemed to revert directly to previously incorporated sports skills and participated both socially and personally in the activity on equal terms with the other participants. Here was no sign of poor visuospatial and visuoconstructive skills, low psychomotor rate, or lack of movement coordination.

Morten himself described his experiences with physical activity in an interview:

"Morten: I have felt good about the sports that I have done.

Interviewer: In what way?

Morten: Well, it distracts your mind.

Interviewer: In what way does it distract your mind? How does it feel?

Morten: Because you only think about training, not about feeling bad or low, you only think about training...and then I am exhausted and tired and feel good about having trained...Training improves your mood.

Interviewer: Do you get fewer bad thoughts, or...?

Morten: Yes, when I'm training?

Interviewer: Yes.

Morten: Yes, I do. My body is sore from having trained and then, how do you say it, then I feel better (...). Training helps, for me, anyway.

Interviewer: It does?

Morten: Yes, it does, it makes me feel great. Because if you have obsessive thoughts, you don't think about it when you train, you only think that you have to train and try to feel good and work hard so your muscles become sore, so it is good to keep going until they are all warm".

Morten lost 55 pounds during the eight months that he participated in the project. According to the staff, his ability to partake in social life at the ward improved, and his desire for spontaneous contact with others increased. Generally, Morten became more integrated and insisted more on his own needs and wishes, 
possibly as a consequence of feeling better about himself and pleased with his own efforts, and having fewer symptoms of disorders and less anxiety in the company of others.

\section{Revival of bodily competence}

In the case of all seven patients, their embedded bodily competences from before the onset of their illnesses were intact or relatively intact even after years of schizophrenia. In other words, the patients were able to participate in football, table tennis, hockey, dance, etc., if this was an activity they had practiced previously. They stepped out of the symptoms and identity of their disease, so to speak, and functioned on a much better level than was suggested by their diagnoses.

This aspect of physical activity is largely overlooked in relation to treatment and should be considered in any treatment course. However, it should be emphasized that there is no causal, deterministic relationship between physical activity and relief from the symptoms of schizophrenia. As suggested by this study, physical activity as a treatment is based on the subjective, incorporated meaning, which can be used as a starting point for activity and treatment.

Within psychiatry, physical activity, motor function, and sensory perception are underestimated as a basis for treatment, agency, and a psychologically well-functioning mind. Often, within psychiatry, the effects of physical activity are seen as being related to factors outside the subject: less coercion, more peace in the ward, prevention, the curing of illnesses, etc. All of these things are important, but physical activity as a treatment is largely underestimated.

Physical activity as a treatment contains a number of related factors, such as social skills, inclusion, empowerment, self-efficacy, and action competence that are crucial for both rehabilitation and recovery. Thus there is good reason to encourage psychiatric treatment facilities, organizations, and decision makers to incorporate what almost seems too banal to be taken seriously: exercise and voluntary physical activities on a body-phenomenological basis.

So why does psychiatry seem disembodied, and how may body phenomenology contribute to an improved understanding of treatment options for patients with schizophrenia?

\section{Understanding of the body within psychiatry}

In another context, I have described how the mind is rooted in the body schema, which is the incorporation of sensory-motor systems and processes that control posture and movement in action. In phenomenological terms, it can be said that the patient's body schema proved intact, which enabled the patient's own body, the body as a condition for experience, to inhabit the world. (Toft, 2011; Svensson, 2001).

Not only did the physical condition of the patients improve, but they also achieved a presence, a contact with themselves, and a self-perception that had until that point been virtually non-existent. In phenomenological terms, it can be said that the body schema facilitated an integration of the patient's body and self-perception in the mind, which resulted in a strengthening of the core self, including ipseity, which is exactly what is missing in the schizophrenic modus.

Psychiatry derives from medical science, a field in which the understanding of the body is scientific. The body is seen as a physical object that can be described based on chemical and physical laws and generalizations, which also include the human psyche. According to the scientific way of thinking, the key to understanding the psyche can be found in the chemical and physical structures of the brain. This understanding is also predominant in the view of physical activity for the prevention of disease and enhancement of health within psychiatry. The general argument is that we, by activating the physical body, can achieve improved health, physically as well as mentally. We can, for example, improve public health in relation to morbidity, mortality, and the reduction of coercion. 
My thesis is that this understanding of the body reduces the body to a piece of meat, i.e., to an objective structure devoid of subjective experience. Several figures within the field of phenomenology give voice to the same standpoint: Collin (2014), Zahavi (2009), and Køppe (2004, 2006) conclude that the scientific perspective of the human body overlooks the subjectivity of the body and mind. At the same time, my argument is that the process of curing mental disorders cannot take place outside an experiencing subject, a subject that is grounded in the body.

In the following, I will present a number of phenomenological concepts that may help elucidate this argument and broaden the general understanding of the relationship between physicality and mental disorder.

\section{PART 2}

\section{Self-consciousness and the body}

"The truth does not 'inhabit' only 'the inner man,' or more accurately, there is no inner man, man is in the world, and only in the world does he know himself. When I return to myself from an excursion into the realm of dogmatic common sense or of science, I find, not a source of intrinsic truth, but a subject destined to the world" (Maurice Merleau-Ponty, The Phenomenology of Perception, 1962 (org. 1945)).

\section{Self-consciousness}

In phenomenological terms, consciousness can be described as partly a primary self-consciousness, and partly a wider, narrative self-consciousness. The primary self-consciousness consists of the core self, which is characterized by an implicit, pre-reflective self-consciousness that requires no self-identification, self-introspection, or other higher-order representation. It is an immediate, lived experience of the world, which can best be described by means of the concept of ipseity. Ipseity, which is a key function in the core self, is defined as the feeling of being a vital subject and is characterized by a first-person perspective in the experience of the world, i.e., a "mineness" in the experience. Consequently, the primary self-consciousness is also referred to as the phenomenal consciousness, as it denotes an experiencing consciousness.

A determining characteristic of the phenomenal consciousness is that it is bound to the body, i.e., embodied. Embodiment refers to the integration of sensory perception, thought, and feeling into a whole in the consciousness. The core self, as part of the phenomenal self, is thus rooted in the body. Because consciousness is understood as both subjective, the experiencing self, and embodied, it is possible in a phenomenological context to talk about a body-subject: an experiencing body, or a subjectivity rooted in the body (Henriksen, 2014; Zahavi, 2002, 2014; Zahavi \& Parnas, 2009; Parnas, 2009; Køppe, 2004; Jacobsen, 2004; Fuchs, 2010).

The core self is thus original, minimal, and characterized by the first-person perspective. It is the basis for making an experience belonging to oneself, whether this experience be a proprioception, thought, conception, sensory perception, or feeling, and it is rooted in the body, which can also be referred to as the body-subject.

Contrary to this, the wider narrative self-consciousness is characterized as based on reflection, internal monitoring, introspection, and a higher-order representation (Zahavi, 2002, 2014; Zahavi \& Parnas, 2009; Parnas, 2009; Fuchs, 2010). As opposed to the phenomenal consciousness, this is a "conscious consciousness": this modus includes the narrative about oneself, seeing oneself as an object. However, the narrative is not fixed, but is continuously constructed and revised through the meeting with the other and the outside world. The way in which one is met in and by the context becomes part of one's self-experience and self-image, and thus part of one's self-narrative (Køppe, 2002).

Self-consciousness may thus be seen as a constant interplay between the phenomenal and the narrative self-consciousness in which the embodied phenomenal consciousness forms the basis for the narrative selfconsciousness. There is no reflection without an underlying subjective experience. 
In this section, I have described that consciousness is rooted in the body. In the following, I elaborate how this entails a special understanding of the body through the concept of one's own body.

\section{One's own body}

According to the phenomenological concept of one's own body, the body is as a condition for experience (Merleau-Ponty, 1962). This should be understood as such that the body stores the bodily experience, which comprises the subjective, phenomenal contents of consciousness. At the same time, one's own body links the self, the other, and the world. The body, so to speak, dissolves the distinction between subject and object, and one's own body thus also forms the basis for an experience of the world as known, relevant, and familiar (Zahavi, 2002, 2014; Zahavi \& Parnas, 2009; Parnas, 2009; Fuchs, 2010). However, it should be emphasized that one's own body forms not only the basis for experience, but also a basis for understanding and structuring experience (Køppe, 2004; Væver, 2004; Merleau-Ponty, 1945; Zahavi \& Parnas, 2009).

As described above, we both have and are a body. On the one hand, the body is the object of an action in progress in which self-consciousness is implicit, automatic, and embodied in the action itself. On the other hand, the body, as the result of an action, becomes an object for consciousness, e.g., in thoughts such as "Why did I drop the glass?" or "Why didn't I score that goal?" Here, the reflecting outer eye observes and assesses the self. Self-consciousness is thus an explicit and willed act (Zahavi, 2002; Zahavi \& Parnas, 2009; Parnas, 2009; Henriksen, 2014).

Similarly, the subjectivity of one's own body determines the extent to which one's subjectivity bores into existence-"I succeeded because I trained!" This can be referred to as an "I can" experience, which both supports and conditions self-experience (Merleau-Ponty, 1962; Jacobsen, 2004). The basis of the reality of consciousness is thus determined by the intentionality of the body, which is intrinsically linked with the ability of the minimal core self to structure action and experience. This self-consciousness is distorted in the schizophrenic modus, in which the delimited, bodily self is constantly endangered.

In Toft (2011), I used case studies to explain how the self-present and delimited self, which has a clear sense of mineness in experience, may be established through physical activity.

\section{Body schema and body image}

Two concepts have played a decisive role in the understanding of body and schizophrenia, namely body schema and body image (Svensson, 2001; Moltke, 2006, 2010; Fuchs, 2010; Køppe, 2004; Sørensen, 2004; Zahavi \& Parnas, 2009). Body schema refers to incorporated sensory-motor systems and processes that control posture and movement in action. It is the way in which the core self inhabits the world as an interwoven, implicit lived experience of the subjective-outer world relation, which arises from a prereflective level of consciousness (Køppe, 2004; Sørensen, 2004; Zahavi \& Parnas, 2009; Parnas, 2009; Fuchs, 2010).

The body schema, understood as habitual and previously embedded competence and experience, has proven relatively intact for many people suffering from schizophrenia, and the body schema from before the onset of the illness is thus imbedded as a subjective basis and resource in the schizophrenic modus (Toft, 2011). Contrary to this, body image refers to a consciousness of one's own body, in which the body (the bodily self) becomes the object of the self. Body image involves perceptual, conceptual, and emotional experiences and attitudes to one's own body (Toft, 2011). Body image thus denotes a reflective level of consciousness.

However, it is important not to see the two concepts as a duality, but rather as an expression of the duality of the body and the oscillation of the consciousness between being (in one's own) body and having a body. The relationship between body schema and body image is dialectic and oscillating-each of them affect 
the other. During physical activity, body image is affected by the body schema and the physical activity itself, creating an experience of mineness or an "I can" experience.

\section{Self-disorder and physical activity}

In psychosis, self-consciousness and the minimal core self are distorted. Employing the concepts revealed above, it can be said that the basis of the core self, the embedded body schema, is dissolved and replaced by a psychotic attempt to maintain meaning (Fuchs, 2010; Sass \& Parnas, 2003; Zahavi, 2002; Zahavi \& Parnas, 2009; Parnas, 2009; Henriksen, 2014). The minimal core self is thus no longer able to maintain either a stable subjectivity or an adaptive reality. In other words, one's own body's familiar habituation of the world is eroded, which leads to disembodiment. The basic condition of the self is lost (Zahavi, 2009; Rosenbaum, 2000). One's own body as a lived experience and integration of subject and the world is distorted, and habitual dispositions no longer seem adequate.

The loss of one's own body's familiar habituation of the world leaves an all-encompassing inner void, which is experienced as disharmony with the outer world. The resulting parallel and inseparable processes of disembodiment and dissolving of self-consciousness entail that body, feeling, and cognition are no longer integrated adequately in the schizophrenic modus.

In accordance with the above, it may be assumed that a reestablishment of the first-person givenness and ipseity in experience will ease the mentioned disembodiment and thus the symptoms of schizophrenia. This, it may be assumed, could be facilitated through physical activity. As mentioned above, the body schema is relatively intact in people with schizophrenia and, consequently, people with schizophrenia stand a good chance of reestablishing a less damaged, possibly even intact, embodiment. In other words, physical activity will strengthen the bodily foundation for self-consciousness, and thus the ipseity. At the same time, this creates a new and different foundation to support the body image. This is the thesis on which the research project at the secure ward in Nykøbing Sjælland, described earlier in this article, was based.

\section{Conclusion}

Above, I have argued that there is a strong correlation between the body, mind, and consciousness, and that the self-disorder witnessed in connection with schizophrenia may be understood as disembodiment. In addition, I have argued that the symptoms of schizophrenia may be eased through physical activity, and that it may thus be advantageous to incorporate physical activity into psychiatric treatment schemes. The empirical foundation for this theoretical argument can be found in Toft (2011), from which the two cases described in this article are taken.

Concerning the question of why symptoms of schizophrenia may be relieved through physical activity, I have employed phenomenological concepts to explain how physical activity may contribute to a greater degree of agency, an improved self-perception, and a greater degree of mineness in experience-functions that are otherwise distorted in people with schizophrenia. This, I have argued, may be connected in part to the fact that physical activity makes the boundaries between subject and object more clear, thus reducing the transitivistic experience. In part, it may be connected with the fact that the sense of reality that is felt during physical activity is given a bodily foundation (Parnas, 2008; Zahavi \& Parnas, 2009) consisting of the lived body and the underlying body schema of one's own body.

\section{REFERENCES}

Biddle, S. \& Mutrie, N. (2008). Psychology of Physical Activity: Determinants, well-being and interventions. London: Routledge.

Daley, J.A. (2002). Exercise therapy and mental health in clinical populations: is exercise therapy a worthwhile intervention? Advances in Psychiatric Treatment, 8, 262-270. 
Faulkner, G. (2005). Exercise as an adjunct treatment for schizophrenia. In Faulkner \& Taylor (Eds.), Exercise, Health and Mental Health (pp. 27-47). London: Routledge.

Faulkner, G. \& Biddle, S. (1999). Exercise as an adjunct treatment for schizophrenia: A review of the literature. Journal of Mental Health, 8(5), 441-457.

Faulkner, G. \& Sparkes, A. (1999). Exercise as therapy for schizophrenia: An ethnographic study. Journal of Sport and Exercise Psychology, 21(1), 52-69.

Fuchs, T. (2010). Phenomenology and psychopathology. In S. Gallagher \& D. Schmicking (Eds.), Handbook of Phenomenology and Cognitive Science (pp. 547-573). Berlin: Springer.

Henriksen, M.G. (2014). Selvforstyrrelser og vrangforestillinger ved skizofreni /Self-disorders and delusions in schizophrenia/. Best Practice, May, 48-51.

Holley, J., Crone, D., Tyson, P. \& Lovell, G. (2011). The effects of physical activity on psychological well-being for those with schizophrenia: A systematic review. British Journal of Clinical Psychology, 50(1), 84-105.

Jacobsen, B. (2004). Den levede krop /The lived body/. In S. Køppe et al. (Eds.), Kroppen i psyken, $139-161$. Copenhagen: Reitzel.

Jørgensen, P., Bredkjær, S. \& Nordentoft, M. (2012). Psykiatriens udfordringer /Challenges for psychiatry/. Copenhagen: Munksgaard.

Køppe, S. (2002). Selvet i psykologiens historie /The self in the history of psychology/. In P. Bertelsen (Eds.), Vinkler på selvet - en antologi om selvbegrebets anvendelse i psykologien /Angles of self - an anthology on the use of the selfconcept in psychology/ (pp. 37-61). Aarhus: Klim.

Køppe, S., Mathiesen, B. Bork, Sørensen, J. Brøsted, Jacobsen B., Væver, M. Skovgaard, Harder, S.,\& Lunn, S. Kroppen i psyken /The body in the mind/. Copenhagen: Hans Reitzels Forlag.

Køppe, S. \& Zeuthen, K. (2006). The skin psyche. Nordisk Tidsskrift for Psykoterapi, 23(3), 237-258).

Merleau-Ponty, M. (1962). Phenomenology of Perception. London: Routledge. (Original work published in 1945)

Moltke, A. (2006). Kropsbilleder ved skizofreni /Body images in schizophrenia/. Psyke og Logos, 27(2), 872-886.

Moltke, A. (2010). Kroppens ambivalens: skizofreni, fysisk aktivitet og motivation /Ambivalence of the body: schizophrenia, physical activity and motivation/. Copenhagen: Frydenlund.

Nordentoft, M., Krogh, J., Lange, P. \& Moltke, A. (2012). Psykisk sygdom og aendringer i livsstil /Mental illness and changes of life stylel. Copenhagen: Vidensråd for Forebyggelse.

Parnas, J. (2008). Begrebet psykose /The concept of psychosis/. Ugeskrift for laeger, 170(46), 3743-3746).

Parnas, J. \& Glenthøj, B. (2009). Skizofreni, skizotypisk sindslidelse, paranoide psykoser, akutte forbigående psykoser samt skizoaffektive psykoser (Schizophrenia, schizotypical disorder, paranoid psychosis, acute transient psychoses and schizoaffective psychoses). In Mors, O., Kragh-Sørensen, P. \& Parnas, J. (Eds.), Klinisk psykiatri (pp. 247-360). Copenhagen: Munksgaard.

Pedersen, B.K. \& Andersen, L.B. (2011). Fysisk aktivitet - håndbog om forebyggelse ogbehandling /Physical activity handbook for prevention and treatment/. Copenhagen: Sundhedsstyrelsen.

Rosenbaum, B. (2000). Tankeformer og talemåder - En undersøgelse af skizofrenes udsigelse, tankeforstyrrelse og kommunikation /Ways of thoughts and modes of speech - An investigation of schizophrenic enunciation, thought disorder and communication/.Copenhagen: Multivers.

Sass, L.A. \& Parnas, J. (2003). Schizophrenia, consciousness, and the self. Schizophrenia Bulletin, 29(3), 427-444.

Stern, D. (2000). Spcedbarnets interpersonelle verden /The interpersonal world of the infant/.Copenhagen: Reitzel.

Svensson, J. (2001). Psykomotorisk trcening i behandlingen af indlagte psykiatriske patienter /Psycho-motoric training for psychiatric patients/. Copenhagen:. Institut for Idræt, Copenhagen University.

Toft, J. (2011). Fysisk aktivitet som behandlingsmetode for skizofrene patienter /Physical activity astreatment method for schziophrenic patients/. Unpublished doctoral dissertation, Copenhagen:Institut for Psykologi, Copenhagen University.

Toft, J. (2014). Evnen til at mærke sig selv /The ability to feel one self/. Social Kritik, 138, 50-53.

Toft, J. \& Ahler, M. (2014). Bevaegelse, krop og sind /Movement, body and mind/. Odense: Institutfor Idræt og Biomekanik, Syddansk Universitet.

Væver, M.S. (2004). Kropslig mening og betydningsdannelse /Bodily constitution of meaning/. In Køppe, S. et al. (Eds.), Kroppen i psyken (pp. 139-161). Copenhagen: Reitzel.

Zahavi, D. (2002). Selvet i filosofisk belysning /The self in philosophical perspective/. In Bertelsen, P. et al. (Eds.), Vinkler på selvet - en antologi om selvbegrebets anvendelse i psykologien (pp. 17-36). Aarhus: Klim. 
Zahavi, D. (2014). Fænomenologi (Phenomenology). In Collin, F. \& Køppe, S. (Eds.), Humanistisk videnskabsteori (pp. 187-222).Copenhagen: Lindhardt.

Zahavi, D. \& Parnas, J. (2009). Bevidsthed - et grundlæggende emne i psykiatrien (Consciousness - a basic topic in psychiatry). In Mors, O. et al. (Eds.), Klinisk psykiatri (pp. 77-102). Copenhagen Munksgaard.

AUTHOR'S ADDRESS: Jim Toft

Slagelse Municipality

Center for Social Psychiatry

Sorøvej 8, 1

DK-4200 Slagelse, Denmark

Email: jim@jimtoft.dk 